\title{
Pembangunan Sistem Monitoring Pengelolaan Benih Tanaman Hutan Berbasis Internet of Things dan Smart Energy
}

\author{
Dedeng Hirawan ${ }^{1}$, Derandi Hermanda ${ }^{2}$ \\ 1,2)Program Studi Teknik Informatika, Fakultas Teknik dan Ilmu Komputer, Universitas Komputer Indonesia \\ Jl. Dipati Ukur No. 112 - 116, Bandung, Indonesia 40132 \\ *email: dedeng@email.unikom.ac.id
}

\begin{abstract}
ABSTRAK - Tujuan dari penelitian ini adalah membantu peneliti benih tanaman hutan dalam memantau benih pada proses perkecambahan (penyemaian). Saat ini jumlah keberhasilan dari perkecambahan kurang dari 50\%, jumlah tersebut tidak sesuai dengan target awal yaitu lebih dari $65 \%$ dari biji tanaman hutan yang disemai, sehingga perlu adanya sistem yang dapat memonitor proses perkecambahan. Metode yang digunakan adalah prototype dengan proses communication, quick plan, modelling quick design, construction of prototype dan development delivery and feedback. Berdasarkan hasil pengujian sistem yang sudah di implementasikan didapatkan, sebelum sistem diimplementasikan benih yang berkecambah sebanyak $65.75 \%$ dari 400 benih, setelah sistem diimplementasikan benih yang berkecambah sebanyak $89.75 \%$ dari 400 benih jadi ketika sistem diimplementasikan benih yang berkecambah meningkat 24\%, sistem dapat menyalakan kipas menghisap udara panas di ruangan ketika suhu melebihi suhu yang di tentukan dan menyalakan water jet pump untuk melakukan penyiraman ketika kelembaban tanah mulai kering dan smart energy yang digunakan menjadi tenaga utama sistem dapat menghidupi sistem selama 24 jam tanpa ada kendala sistem padam.
\end{abstract}

Kata Kunci - Monitoring; Benih Tanaman; Smart Energy; Internet of Things; Perkecambahan.

\section{Development of Monitoring Systems for Forest Plant Seed}

\section{Based on Internet of Things and Smart Energy}

\begin{abstract}
The purpose of this study is to help researchers plant seed forest in monitoring the seeds on the germination process (seeding). Currently the amount of success of the germination is less than 50\%, the amount is not in accordance with the initial target of more than $65 \%$ of the seeds forest plant, so there needs to be a system that can monitor the process of seeding.. The method used is the prototype with the communication process, quick plan, quick design modeling, construction of the prototype and development of delivery and feedback. Based on the results of testing the system that has been implemented, it is obtained, before the system is implemented that seeds germinate as much as $65.75 \%$ of the 400 seeds, after the system is implemented the seeds germinate as much as $89.75 \%$ of the 400 seeds so when the system is implemented the germinated seeds increase by $24 \%$, the system can turn on the fan suck hot air in the room when the temperature exceeds the specified temperature and turn on the water jet pump to do the watering when soil moisture starts to dry and the smart energy used to be the main power of the system can support the system for 24 hours without any system outages..
\end{abstract}

Keywords - Monitoring; Forest Plant Seed; Smart Energy; Internet of Things; Seeding.

\section{Pendahuluan}

Benih tanaman merupakan jasad hidup yang berfungsi sebagai sarana untuk reproduksi tanaman, benih merupakan hasil namanan yang juga merupakan awal kehidupan yang sangat menentukan kelangsungan generasi berikutnya [7]. Permasalahan muncul saat proses Uji
Perkecambahaan/ Uji Visabilitas adalah sulitnya mengatur suhu ruangan pengujian yang panas pada siang hari dan juga proses penyiraman tanaman yang tidak teratur.

Setiap data pengujian tidak tercatat dengan baik seperti berapa suhu ruangan yang tepat untuk suatu bibit tanaman hutan berkecambah dan jenis tanah yang digunakan pada saat pengujian perkecambahan 
benih. Selanjutnya ketika sudah jam pulang kerja atau pun hari libur maka ruangan pengujian sudah tidak terurus sehingga proses penyiraman tidak di lakukan lagi menyebabkan pengujian terhambar dan juga dari 1000 butir benih yang tumbuh hanya sekitar $45 \%$ dari total dan jugaakses listrik ke ruangan pengujian sering terjadinya pemadaman dan tegangan listrik yang naik turun atau tidak stabil sehingga perlu energy alternative yang akan menjadi tenaga listrik utama di ruangan pengujian.

Berdasarkan masalah yang telah diuraikan tersebut untuk melakukan pengelolaan benih tanaman hutan adalah dengan menciptakan alat yang berperan sebagai media monitoring dan pengkontrolan ruangan pengujian.

\section{METODE DAN BAHAN}

Pada penelitian ini digunakan metode prototyping dalam proses pembangunan perangkat lunak dan perangkat keras. Hal ini dikarenakan pada pembuatan sistem, keterlibatan pengguna sangat tinggi sehingga sistem diharapkan dapat memenuhi kebutuhan pengguna dengan lebih baik $[4,5]$. Dimuat dalam gambar 1.

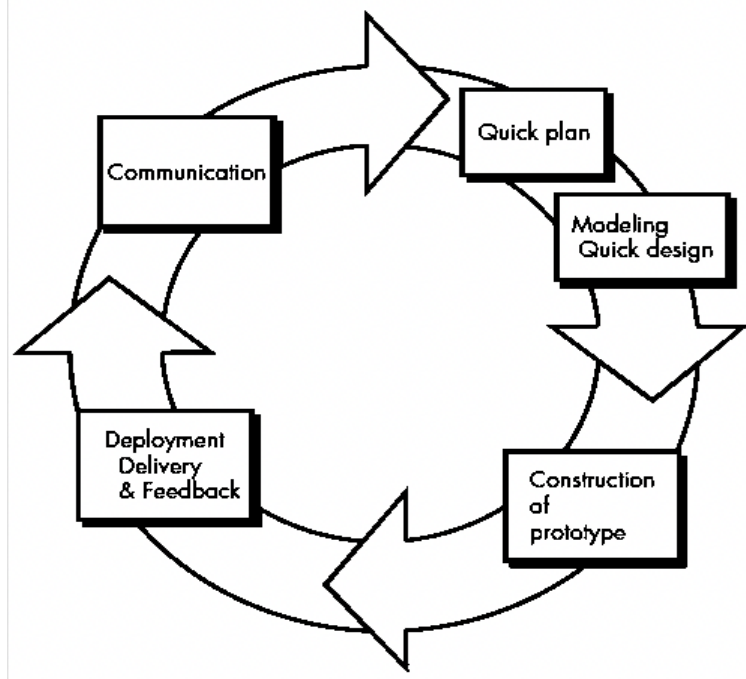

Gambar 1. Metode Prototyping

Penjelasan point metode prototyping adalah sebagai berikut :

\section{Communication}

Peneliti melakukan analisis kebutuhan sistem dengan mengumpulkan data, yaitu dengan melakukan wawancara dengan penguji Balai Perbenihan Tanaman Hutan, serta mengumpulkan data-data tambahan baik yang ada di jurnal maupun di buku.

\section{Quick Plan}

Peneliti pada tahap ini melanjutkan dari proses communication. Pada tahap ini dihasilkan data yang berhubungan dengan keinginan pengguna dalam pemabngunan sistem, yaitu sebuah sistem yang dapat mengawasi dan mengelola perkecambahan tanaman hutan yang dapat mengurangi kegagalan perkecambahan benih tanaman hutan.

\section{Modelling Quick Design}

Peneliti mulai melakukan sebuah perancangan sistem sesuai dengan kebutuhan dari penguji Balai Perbenihan Tanaman Hutan (BPTH) yang dapat diperkirakan sebelum proses pengkodean. Proses modeling quick design ini dilakukan dengan merancang struktur data, arsitektur software dan unified modeling language (UML).

\section{Construction of Prototype}

Pada tahap ini peneliti mulai melakukan pengkodean yaitu membangun sistem sesuai dengan perencanaan pada tahap modeling quick design, melakukan pengkodean pada Raspberry Pi untuk mengatur fungsi sensor DHT 22, Soil Moisture, voltage dan ampere untuk mengambil dan menampilkan data sensor pada website, mengaktifkan relay untuk menyalakan exaust fan ketika suhu ruangan pengujian melebih batas yang sudah di tentukan dan menyalakan water jet pump ketika kelembaban tanah mulai kering, serta menyimpan data benih dan penggujian yang sudah di lakukan di Raspberry Pi. Setelah pengkodean selesai selanjutnya dilakukan pengujian terhadap sistem yang telah dibangun, tujuannya ada menemukan kesalahan-kesalahan terhadap sistem tersebut untuk kemudian bisa di perbaiki.

\section{Developtment Delivery \& Feedback}

Tahap ini bisa dikatan final dalam pembuatan sebuah sistem. Setelah melakukan analisis, desain dan pengkodean, maka sistem yang sudah jadi akan digunakan oleh pengguna, kemudian sistem yang telah dibangun dilakukan pemeliharaan atau maintenance secara berkala.

\section{HASIL DAN PEMBAHASAN}

\subsection{Internet of Things}

Internet of Things (IOT) terdiri dari 2 pilar utama yaitu "internet" dan "Things", jadi setiap objek yang mampu terhubung ke internet akan masuk ke dalam kategori "Things" seperti mencakup seperangkat entitas yang lebbih umum seperti smartphone, sensors, manusia dan objek lainnya. Konteksnya mampu berkomunikasi dengan entitas lain, membuatnya dapat diakses kapan saja, dimana saja. Secara garis besar dengan Internet of Things (IOT) objek harus dapat diakses tanpa batasan waktu atau tempat $[1,2]$. 

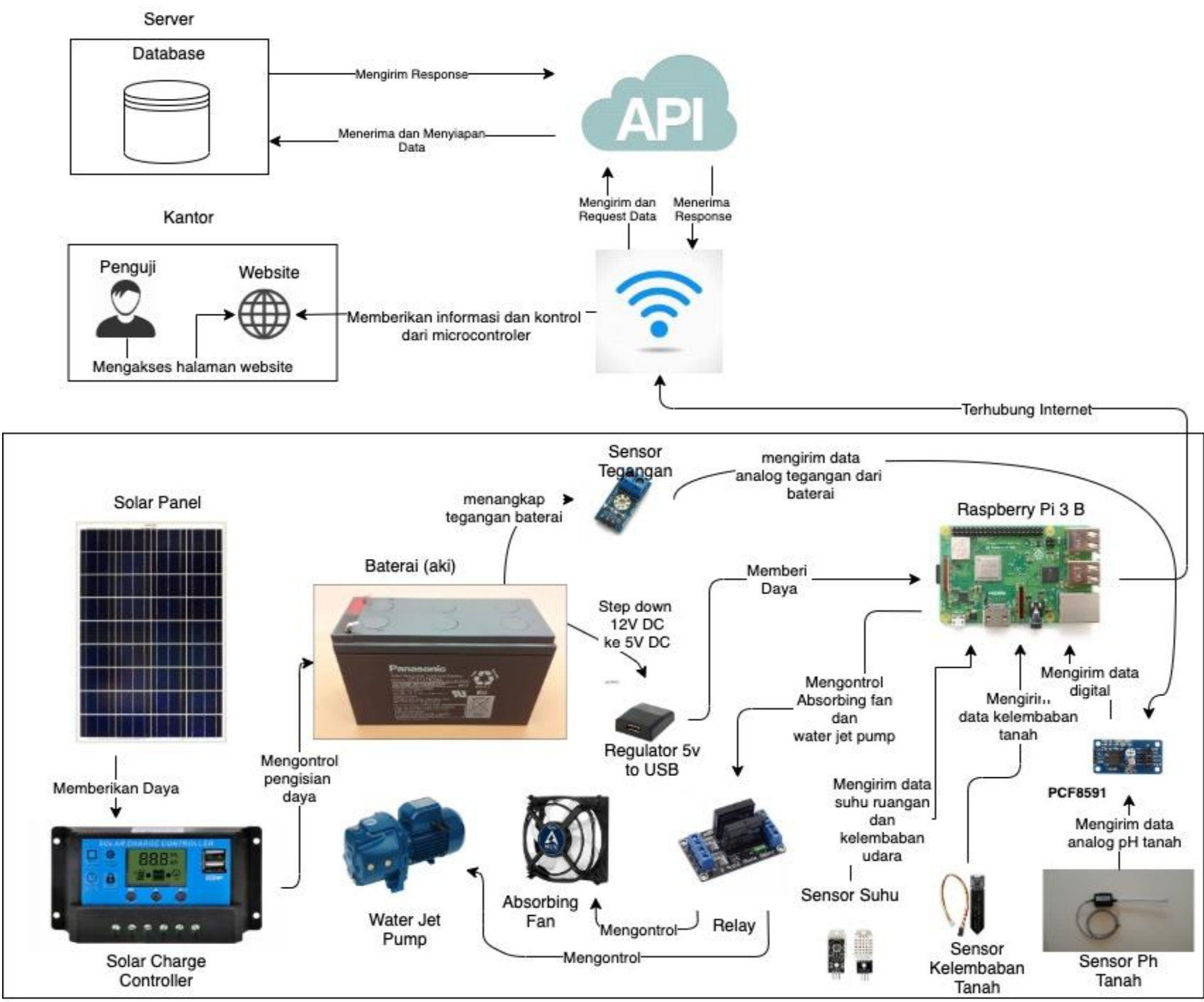

Ruang Pengujian Benih

Gambar 2. Analisis Arsitektur Sistem

\subsection{Arsitektur Sistem}

Arsitektur sistem merupakan sebuah proses untuk mendeskripsikan fisik sistem yang akan dibangun dan juga komponen-komponen pedukungnya. Berikut adalah gambaran dari arsitektur sistem yang akan dibangun dapat dilihat pada gambar 2 .

Berikut ini adalah penjelasan dari gambaran arsitektur pembangunan sistem sistem pengelolaan benih tanaman hutan menggunakan Internet of Things (IOT) dan smart energy, sebagai berikut:

1. Aplikasi web akan digunakan oleh penguji, penguji dapat melihat keadaan suhu ruangan, kelembaban ruangan, kelembaban tanah bak pengujian dan ph tanah bak pengujian, penguji juga dapat melakuakn pengendalian perangkat.

2. Webservice digunakan sebagai mengirim data antara sensor dan halaman website.
3. Pengisian baterai dikontrol oleh solar charge controller untuk menghindari over charge ketika mendapatkan daya dari solar panel. [6]

4. Regulator $5 \mathrm{~V}$ digunakan untuk step down arus $12 \mathrm{~V}$ DC dari baterai ke 5V DC sehingga dapat memberikan daya untuk Raspberry Pi 3B.[6]

5. Relay 2 channel digunakan untuk mengaktifkan absorbing fan ketika suhu ruangan melebihi batas yang sudah di atur oleh penguji dan mengaktifkan water jet pump ketika kelembaban tanah mulai kering dari data sensor soil moisture.

6. Sensor suhu dan kelembaban menggunakan DHT 22, data sensor ini digunakan untuk mengukur suhu serta kelembaban udara ruangan pengujian.

7. Sensor kelembaban tanah, data sensor ini digunakan untuk mengukur tingkat kelembaban tanah bak pengujian. 


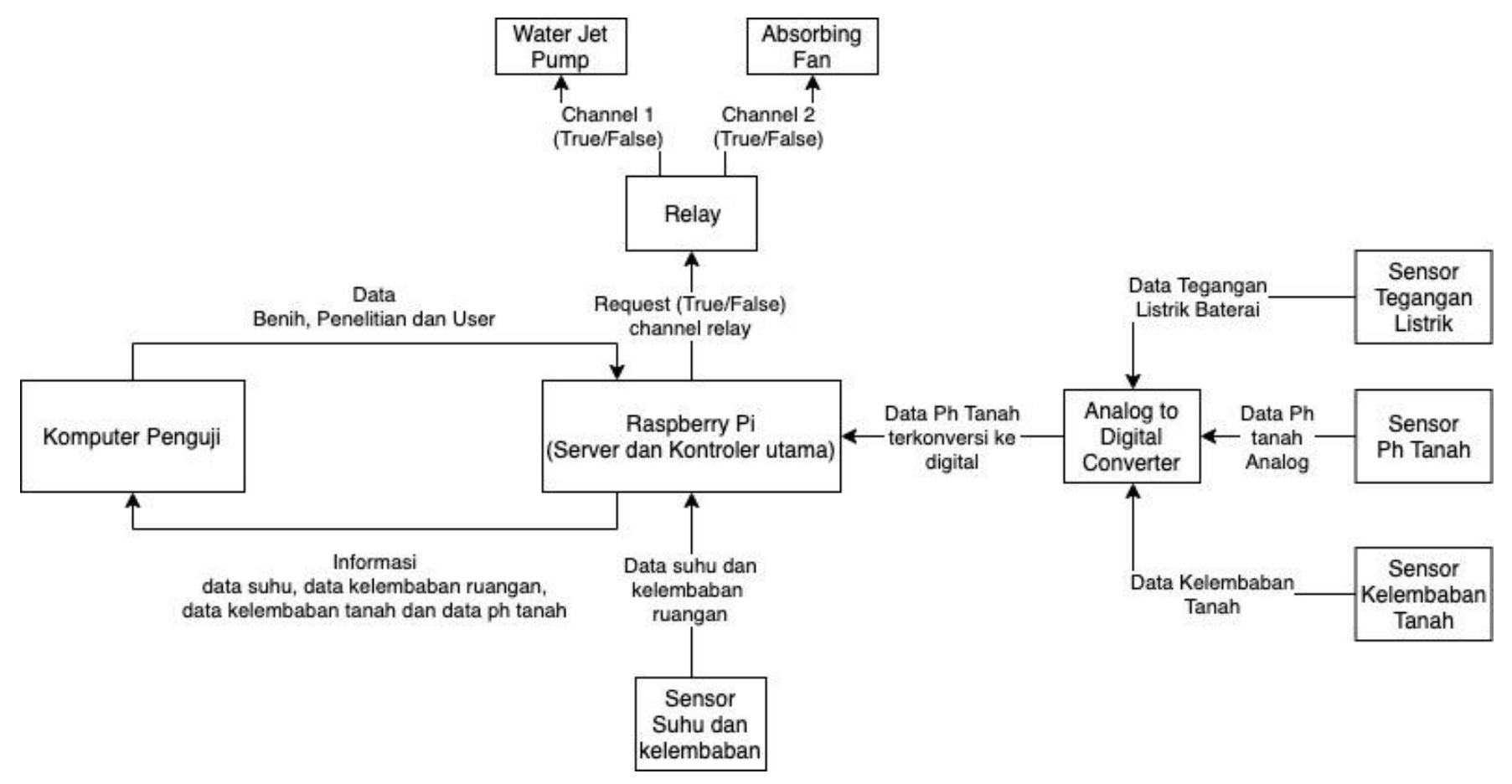

Gambar 3. Alur Komunikasi Data

8. Data sensor ph tanah dan sensor tegangan dari analog di konversi menjadi digital menggunakan PCF8591 lalu data digunakan untuk mengukur keasaman tanah bak pengujian.

9. Solar panel sebagai smart energy mengubah cahaya matahari ke listrik digunakan sebagai sumber listrik utama.

\subsection{Analisis Komunikasi Data}

Komunikasi data merupakan suatu hal yang sangat penting dalam pembangunan sebuah aplikasi. Karena tanpa adanya komunikasi data, suatu aplikasi yang dibangun tidak akan bisa berjalan dengan semestinya. Komunikasi data yang digunakan pada sistem pengelolaan benih tanaman hutan menggunakan media internet dan smart energy ini adalah komunikasi antara Raspberry Pi dengan sensor dan modul relay dan Raspberry Pi dengan website menggunakan JSON [3,8]. Alur komunikasi data dapat dilihat pada gambar 3 .

Berikut ini adalah penjelasan dari alur komunikasi data :

1. Semua sensor mengirim data ke Rasberry Pi.

2. Raspberry Pi mengirimkan data dari sensor ke website dengan JSON secara real-time delay time 1 detik atau secara berkala.

3. Penguji mengirim data user, penelitian dan benih ke Raspberry Pi, dan data langsung di simpan dalam bentuk log data.
4. Raspberry Pi akan memberikan trigger true pada relay channel 1 ketika kelembaban tanah sudah kering berkisar antara 10-30\% kadar air di dalam tanah, ketika tanah sudah lembab maka membrikan trigger false, dan pada relay channel 2 raspberry pi akan memberikan trigger true ketika suhu ruangan melebihi batas yang sudah di tentukan oleh peneliti, ketika suhu ruangan sudah normal atau di bawah batas maka memberikan trigger false.

\subsection{Use Case Diagram}

Use case diagram merupakan pemodelan untuk behaviour sistem yang akan dibuat [9]. Untuk mendeskripsikan hubungan yang terjadi antar actor dengan aktivitas yang terdapat pada sistem. Use Case Diagram yang dirancang dapat dilihat pada gambar 4.

\subsection{Class Diagram}

Class Diagram merupakan gambaran dari struktur dan hubungan pada setiap objek-objek yang berjalan pada system. Class Diagram yang dirancang dapat dilihat pada gambar 5 .

\subsection{Skema Relasi}

Skema relasi adalah rangkaian hubungan antara beberapa tabel pada sistem basis data. Skema relasi yang dirancang dapat dilihat pada gambar 6 . 
D Hirawan \& D Hermanda

Komputika: Jurnal Sistem Komputer, Vol. 8, No. 2, Oktober 2019

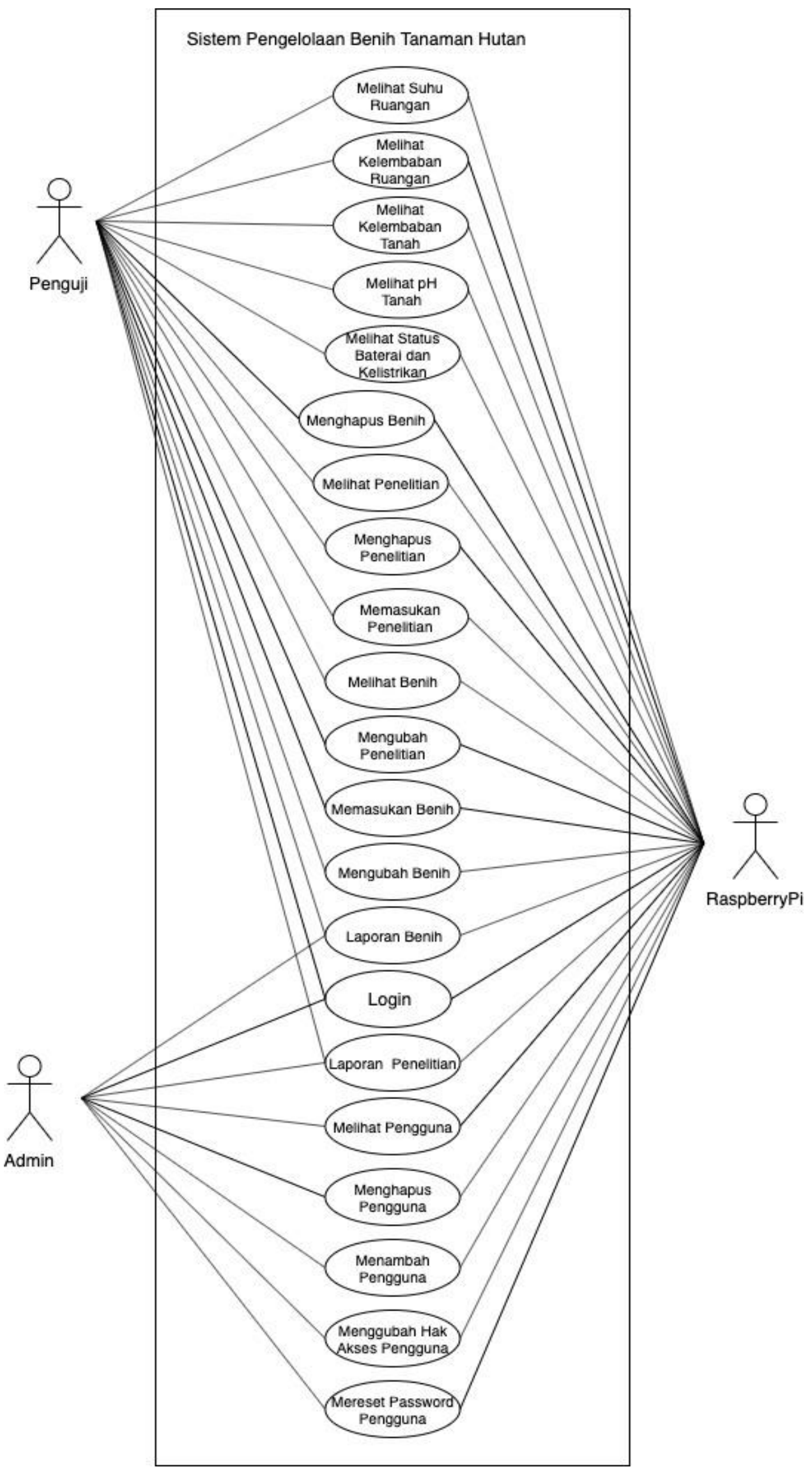

Gambar 4. Use case Diagram 
D Hirawan \& D Hermanda

Komputika: Jurnal Sistem Komputer, Vol. 8, No. 2, Oktober 2019

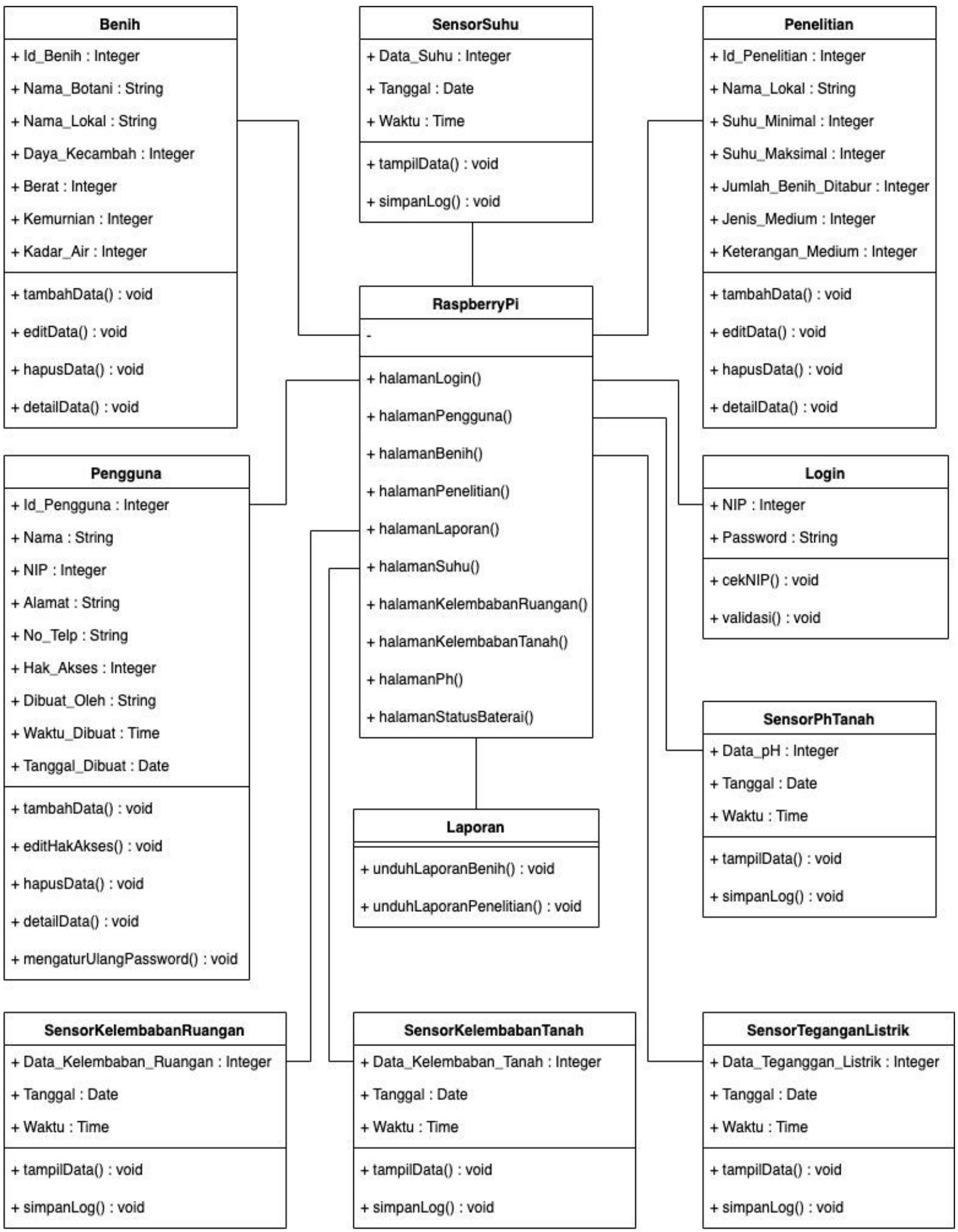

Gambar 5. Class Diagram 
D Hirawan \& D Hermanda

Komputika: Jurnal Sistem Komputer, Vol. 8, No. 2, Oktober 2019

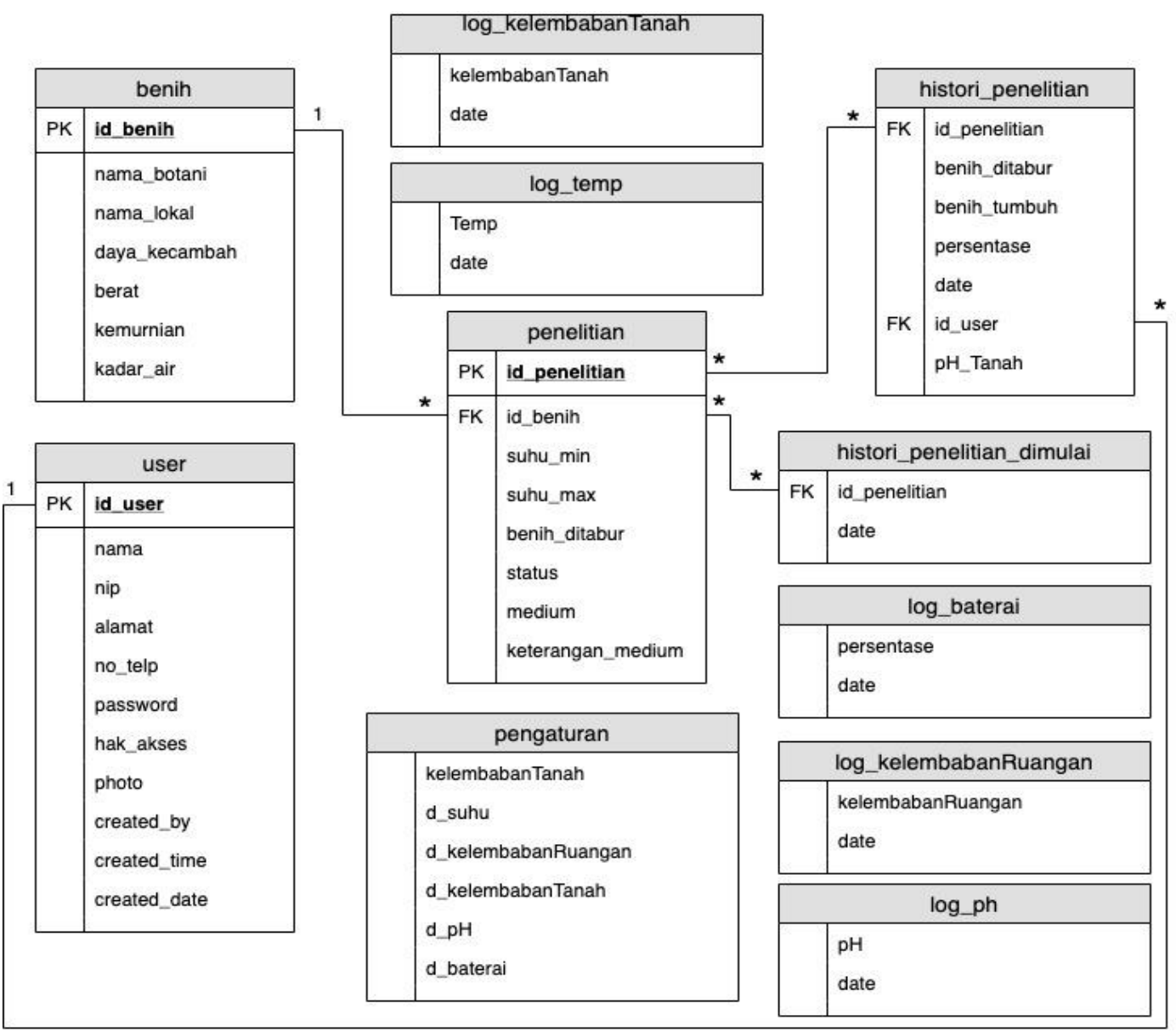

Gambar 6. Skema relasi

\subsection{Hasil Pengujian}

Pengujian sistem merupakan hal terpenting yang bertujuan untuk menemukan kesalahan atau kekurangan pada sistem informasi yang diuji. Pengujian sistem dimaksud untuk mengetahui kinerja sistem informasi yang telah dibuat sesuai dengan tujuan perancangan sistem informasi. Tipe testing yang dilakukan yaitu meliputi Testing Functionality dan Usability.

\subsubsection{Pengujian Black Box}

Pengujian black box berfokus pada apakah perangkat lunak yang dibangun memenuhi kebutuhan yang disebutkan dalam spesifikasi [10]. Pengujian dilakukan dengan menjalankan atau mengeksekusi unit, kemudian diamati apakah hasil dari unit yang diuji tersebut apakah sesuai dengan yang diharapkan atau tidak.

Skenario pengujian perangkat lunak untuk penguji pada pembangunan sistem monitoring pengelolaan benih tanaman hutan berbasis internet of things dan smart energy dapat dilihat pada tabel 1.
Tabel 1. Skenario Pengujian Black Box

\begin{tabular}{|c|c|c|}
\hline Kasus Uji & Detail Pengujian & $\begin{array}{c}\text { Jenis } \\
\text { Pengujian }\end{array}$ \\
\hline Login & Login penguji & Black Box \\
\hline Memulai & Memulai penelitian pengujian & Black Box \\
\hline Penelitian & benih & \\
\hline $\begin{array}{l}\text { Mengakhiri } \\
\text { Penelitian }\end{array}$ & $\begin{array}{l}\text { Menyelesaikan penelitian } \\
\text { pengujian benih }\end{array}$ & Black Box \\
\hline $\begin{array}{l}\text { Ubah Data } \\
\text { Pengaturan } \\
\text { Alat }\end{array}$ & $\begin{array}{l}\text { Merubah data pengaturan } \\
\text { waktu dan batas kelembaban } \\
\text { tanah. }\end{array}$ & Black Box \\
\hline Benih & Melihat data list benih & Black Box \\
\hline $\begin{array}{l}\text { Tambah Data } \\
\text { Benih }\end{array}$ & Menambah data benih & Black Box \\
\hline $\begin{array}{l}\text { Detail Data } \\
\text { Benih }\end{array}$ & Melihat data detail benih & Black Box \\
\hline $\begin{array}{l}\text { Ubah Data } \\
\text { Benih }\end{array}$ & Merubah data benih & Black Box \\
\hline $\begin{array}{l}\text { Hapus Data } \\
\text { Benih }\end{array}$ & Menghapus data benih & Black Box \\
\hline Penelitian & Melihat data list penelitian & Black Box \\
\hline $\begin{array}{l}\text { Tambah Data } \\
\text { Penelitian }\end{array}$ & Menambah data penelitian & Black Box \\
\hline $\begin{array}{l}\text { Detail Data } \\
\text { Penelitian }\end{array}$ & Melihat data detail penelitian & Black Box \\
\hline $\begin{array}{l}\text { Ubah Data } \\
\text { Penelitian }\end{array}$ & Merubah data penelitian & Black Box \\
\hline $\begin{array}{l}\text { Hapus Data } \\
\text { Penelitian }\end{array}$ & Menghapus data penelitian & Black Box \\
\hline
\end{tabular}


D Hirawan \& D Hermanda

Komputika: Jurnal Sistem Komputer, Vol. 8, No. 2, Oktober 2019

\begin{tabular}{llc}
\hline \multicolumn{1}{c}{ Kasus Uji } & \multicolumn{1}{c}{ Detail Pengujian } & \multicolumn{1}{c}{$\begin{array}{c}\text { Jenis } \\
\text { Pengujian }\end{array}$} \\
\hline $\begin{array}{l}\text { Melihat File } \\
\text { Excel Laporan }\end{array}$ & $\begin{array}{l}\text { Melihat file berisi data list } \\
\text { benih }\end{array}$ & Black Box \\
$\begin{array}{l}\text { Data Benih } \\
\text { Melihat File }\end{array}$ & $\begin{array}{l}\text { Melihat file berisi data list } \\
\text { Excel Laporan }\end{array}$ & Black Box \\
$\begin{array}{l}\text { Data } \\
\text { Penelitian }\end{array}$ & \\
Ubah Data & $\begin{array}{l}\text { Mengubah data akun } \\
\text { Akun }\end{array}$ & Black Box \\
Ubah & $\begin{array}{l}\text { Mengubaha data password } \\
\text { Password }\end{array}$ & Black Box \\
\hline
\end{tabular}

\subsubsection{Kesimpulan Pengujian Black Box}

Berdasarkan hasil pengujian Black Box yang telah dilkaukan maka dapat disimpulkan bahwa secara fungsional seluruh proses pada sistem sebagian telah berjalan sesuai dengan yang di harapkan.

\subsection{Pengujian Komponen Perangkat Keras}

Pengujian komponen perangkat keras bertujuan utnuk mengetahui karakteristik dari setiap komponen yang digunakan dan utnuk mengetahui apakah tiap komponen dalam kondisi baik atau tidak, sehingga dapat memaksimalkan fungsi dari setiap komponen agar selanjutnya dapat digunakan pada sistem yang dibuat, tampilan dapat dilihat pada gambar 7.

\subsubsection{Pengujian Sensor $\mathbf{p H}$ Tanah}

Sensor $\mathrm{pH}$ Tanah merupakan sensor pendeteksi tingkat keasaman (acid) atau kebasaan (alkali) tanah, hasil pengujian dapat dilihat pada tabel 2 .

\begin{tabular}{ccc}
\multicolumn{3}{c}{ Tabel 2. Hasil Pengujian Sensor pH Tanah } \\
\hline Tanggal & Jam & pH \\
\hline $2019-07-12$ & $08: 17: 36$ & 7 \\
$2019-07-12$ & $08: 20: 37$ & 7 \\
$2019-07-12$ & $08: 23: 38$ & 7 \\
$2019-07-12$ & $08: 26: 38$ & 7 \\
$2019-07-12$ & $08: 29: 39$ & 7 \\
$2019-07-12$ & $08: 32: 40$ & 7 \\
$2019-07-12$ & $08: 35: 43$ & 7 \\
$2019-07-12$ & $08: 38: 43$ & 7 \\
$2019-07-12$ & $08: 41: 44$ & 7 \\
$2019-07-12$ & $08: 44: 45$ & 7 \\
$2019-07-12$ & $08: 47: 45$ & 7 \\
$2019-07-12$ & $08: 50: 46$ & 7 \\
$2019-07-12$ & $08: 53: 47$ & 7 \\
$2019-07-12$ & $08: 56: 47$ & 7 \\
$2019-07-12$ & $08: 59: 48$ & 7 \\
$2019-07-12$ & $09: 02: 49$ & 7 \\
$2019-07-12$ & $09: 05: 49$ & 7 \\
$2019-07-12$ & $09: 08: 53$ & 7 \\
$2019-07-12$ & $09: 11: 53$ & 7 \\
$2019-07-12$ & $08: 17: 36$ & 7 \\
\hline
\end{tabular}

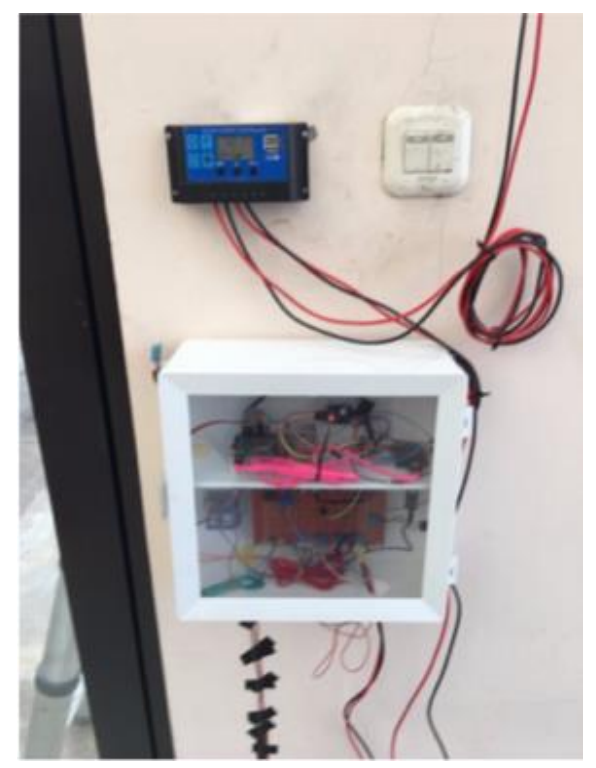

Gambar 7. Tampilan Alat

\subsubsection{Pengujian Sensor DHT 22}

Sensor DHT 22 merupakan sensor yang digunakan untuk mengukur suhu dan kelembaban udara, pengujian nilai akurasi sensor dht 22 dengan membandingkan dengan thermo-hygrometer digital di ruangan pengujian dapat dilihat pada tabel 3 .

Tabel 3. Hasil Pengujian Sensor DHT 22

\begin{tabular}{cccc}
\hline Tanggal & Jam & Suhu $\left({ }^{\circ} \mathrm{C}\right)$ & $\begin{array}{c}\text { Kelembaban } \\
(\mathbf{\%})\end{array}$ \\
\hline $2019-07-12$ & $08: 17: 36$ & 25 & 39 \\
$2019-07-12$ & $08: 20: 37$ & 25 & 38 \\
$2019-07-12$ & $08: 23: 38$ & 25 & 38 \\
$2019-07-12$ & $08: 26: 38$ & 25 & 36 \\
$2019-07-12$ & $08: 29: 39$ & 25 & 35 \\
$2019-07-12$ & $08: 32: 40$ & 12 & 35 \\
$2019-07-12$ & $08: 35: 43$ & 25 & 36 \\
$2019-07-12$ & $08: 38: 43$ & 25 & 34 \\
$2019-07-12$ & $08: 41: 44$ & 25 & 35 \\
$2019-07-12$ & $08: 44: 45$ & 25 & 33 \\
$2019-07-13$ & $08: 01: 27$ & 25 & 34 \\
$2019-07-13$ & $08: 04: 27$ & 25 & 34 \\
$2019-07-13$ & $08: 07: 28$ & 25 & 33 \\
$2019-07-13$ & $08: 10: 29$ & 25 & 33 \\
$2019-07-13$ & $08: 13: 32$ & 25 & 33 \\
$2019-07-13$ & $08: 16: 32$ & 25 & 34 \\
$2019-07-13$ & $08: 19: 33$ & 25 & 31 \\
$2019-07-13$ & $08: 22: 34$ & 25 & 32 \\
$2019-07-13$ & $08: 25: 34$ & 25 & 29 \\
$2019-07-13$ & $08: 28: 35$ & 25 & 29 \\
\hline Rata - Rata & 24 & 30 \\
\hline
\end{tabular}


D Hirawan \& D Hermanda

Komputika: Jurnal Sistem Komputer, Vol. 8, No. 2, Oktober 2019

Tabel 4. Hasil Pengujian Sensor Kelembaban Tanah

\begin{tabular}{cccc}
\hline Tanggal & Jam & $\begin{array}{c}\text { Nilai } \\
\text { Kelembaban } \\
\text { Tanah (\%) }\end{array}$ & $\begin{array}{c}\text { Keadaan } \\
\text { Tanah }\end{array}$ \\
\hline 2019-07-12 & $08: 02: 31$ & 43 & Kering \\
2019-07-12 & $08: 05: 31$ & 43 & Kering \\
2019-07-12 & $08: 08: 32$ & 43 & Kering \\
2019-07-12 & $08: 11: 32$ & 43 & Kering \\
2019-07-12 & $08: 14: 33$ & 43 & Kering \\
2019-07-12 & $08: 17: 36$ & 43 & Kering \\
2019-07-12 & $08: 20: 37$ & 43 & Kering \\
2019-07-12 & $08: 23: 38$ & 43 & Kering \\
2019-07-12 & $08: 26: 38$ & 43 & Kering \\
2019-07-12 & $08: 29: 36$ & 43 & Kering \\
2019-07-12 & $11: 55: 00$ & 89 & Basah \\
2019-07-12 & $11: 58: 02$ & 89 & Basah \\
2019-07-12 & $12: 01: 04$ & 89 & Basah \\
2019-07-12 & $12: 04: 06$ & 89 & Basah \\
$2019-07-12$ & $12: 07: 08$ & 89 & Basah \\
2019-07-12 & $12: 10: 10$ & 89 & Basah \\
$2019-07-12$ & $12: 13: 12$ & 89 & Basah \\
$2019-07-12$ & $12: 16: 14$ & 89 & Basah \\
$2019-07-12$ & $12: 19: 16$ & 89 & Basah \\
2019-07-12 & $12: 22: 17$ & 89 & Basah \\
\hline & & & \\
\hline
\end{tabular}

\subsubsection{Pengujian Sensor Kelembaban Tanah}

Pengujian sensor kelembaban tanah dilakukan dengan sensor di simpan pada tanah kering dan di ambil nilai yang terbaca pada saat kering lalu di simpan pada tanah yang basah dan di ambil nilai yang terbaca pada saat basah, hasil pengujian dapat dilihat pada tabel 4 .

\subsubsection{Pengujian Penggunaan Baterai}

Pengujian relay dilakukan dengan menghubungkan fan $12 \mathrm{~V}$ dan water jet pump, secara umum relay merupakan komponen elektromekanikal yang berfungsi sebagai sakelar dengan memanfaatkan prinsip kerja elektromagnetika untuk menggerakan kontak saklar sehingga dapat menghantarkan listrik yang bertegangan lebih tinggi AC maupun DC hanya dengan harus listrik yang kecil, hasil pengujian dapat dilihat pada tabel 5. [2]

\subsubsection{Pengujian Pengelolaan Benih}

Pengujian pengelolaan benih dilakukan dengan cara membandingkan data pengujian sebelum sistem terpasang dengan data setelah sistem terpasang. Dari hasil pengujian dapat diambil kesimpulan, sebelum sistem dipasang pengujian berlangsung 14 hari dengan persentase benih berkecambah $65.75 \%$ dan sesudah sistem dipasang pengujian berlangsung 11 hari dengan persentase benih berkecambah $89.75 \%$,
Tabel 5. Hasil Pengujian Penggunaan Baterai

\begin{tabular}{cccc}
\hline Tanggal & Waktu & $\begin{array}{c}\text { Persentase } \\
\text { Daya Baterai } \\
(\%)\end{array}$ & $\begin{array}{c}\text { Tegangan } \\
\text { Baterai }(\mathbf{V})\end{array}$ \\
\hline $17 / 07 / 19$ & 23.30 & 100 & 12.09 \\
$17 / 07 / 19$ & 23.30 & 100 & 12.09 \\
$18 / 07 / 19$ & 00.14 & 72.07 & 12.03 \\
$18 / 07 / 19$ & 00.26 & 68.04 & 12.05 \\
$18 / 07 / 19$ & 00.38 & 68.08 & 12.07 \\
$18 / 07 / 19$ & 00.50 & 68.08 & 12.06 \\
$18 / 07 / 19$ & 01.02 & 68.04 & 12.06 \\
$18 / 07 / 19$ & 01.14 & 68.04 & 12.07 \\
$18 / 07 / 19$ & 01.26 & 68.08 & 12.05 \\
$18 / 07 / 19$ & 01.38 & 68.08 & 12.06 \\
$18 / 07 / 19$ & 01.50 & 68.08 & 12.06 \\
$18 / 07 / 19$ & 02.02 & 68.08 & 12.06 \\
$18 / 07 / 19$ & 02.14 & 68.04 & 12.06 \\
$18 / 07 / 19$ & 02.26 & 68.04 & 12.05 \\
$18 / 07 / 19$ & 02.38 & 68.08 & 12.04 \\
$18 / 07 / 19$ & 02.50 & 68.04 & 12.05 \\
$18 / 07 / 19$ & 03.02 & 68.08 & 12.06 \\
$18 / 07 / 19$ & 03.14 & 68.04 & 12.04 \\
$18 / 07 / 19$ & 03.26 & 68.08 & 12.06 \\
$18 / 07 / 19$ & 03.38 & 68.08 & 12.06 \\
\hline & & &
\end{tabular}

perbadingan persentase benih berkecambah sebelum sistem dipasang dan sesudah dipasang sebesar $24 \%$. Sesudah sistem dipasang pengujian lebih cepat 3 hari sehingga dengan sistem dipasang benih berkecambah meningkat sebesar $24 \%$ dan pengujian lebih cepat 3 hari. Hal ini dapat dipengaruhi oleh keadaan suhu yang sudah diatur berdasarkan nilai dari sensor DHT 22, siklus penyiraman bibit berdasarkan nilai dari sensor kelembaban tanah dan kondisi $\mathrm{pH}$ tanah yang sesuai dengan kebutuhan bibit. Foto pengujian dapat dilihat pada gambar 8 dan 9.

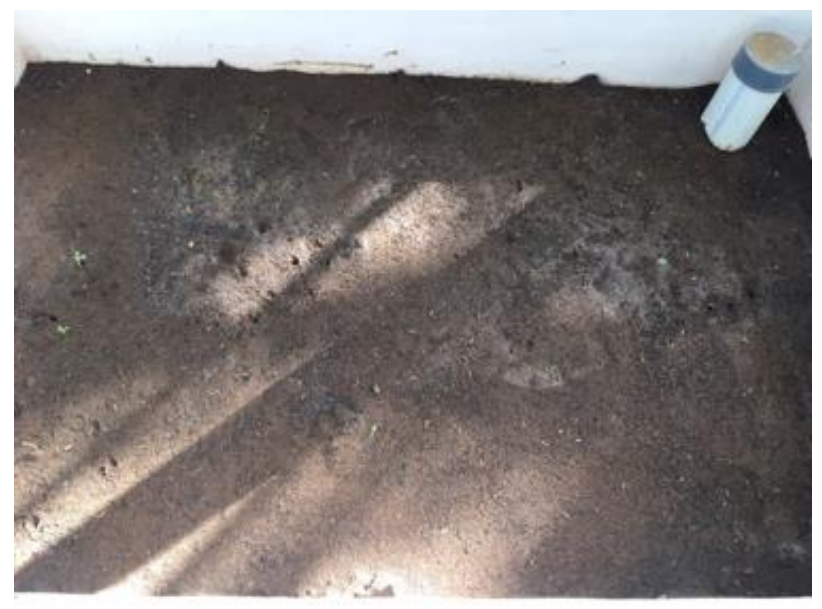

Gambar 8. Sebelum Benih Tumbuh 


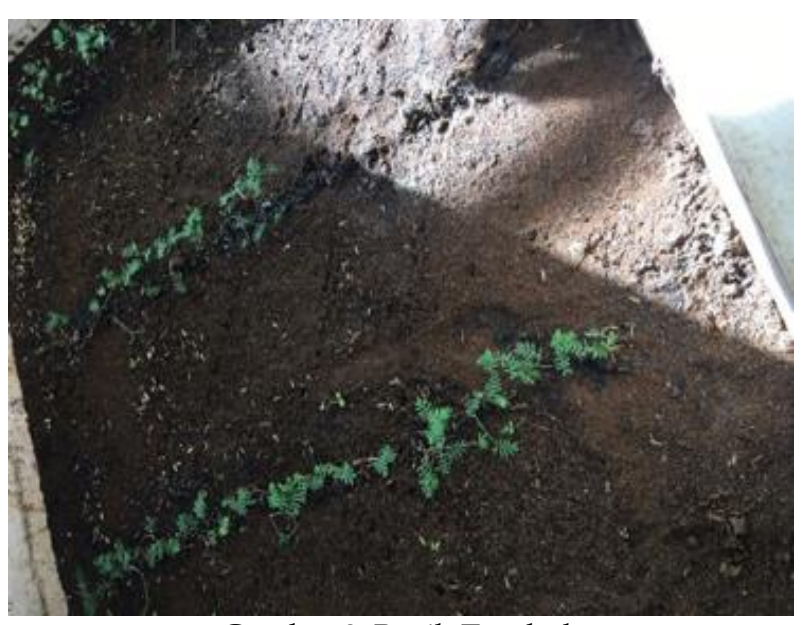

Gambar 9. Benih Tumbuh

\section{KESIMPULAN}

Berdasarkan hasil pengujian perangkat lunak dan perangkat keras yang telah dibuat sebagai sistem monitoring pengelolaan benih tanaman hutan berbasis IOT dan smart energy maka diperoleh kesimpulan sebagai berikut: (1) Sistem yang telah dibangun dapat meningkatkan perkecambahan benih di atas rata-rata hingga $24 \%$, (2) Sistem dapat menyalakan kipas menghisap udara panas di ruangan ketika suhu melebih suhu yang di tentukan dan menyalakan water jet pump untuk melakukan penyiraman ketika kelembaban tanah mulai kering, (3) Energy Matahari (solar energy) yang diubah menjadi tenaga listrik dengan solar panel yang menjadi tenaga utama sistem dapat menghidupi sistem selama 24 jam tanpa ada kendala sistem padam.

\section{DAFTAR PUSTAKA}

[1] R. Buyya and A. V. Dastjerdi, Internet of Things: principles and paradigms. Amsterdam: Morgan Kaufmann, 2016.

[2] H. Lund, P. A. Østergaard, D. Connolly, and B. V. Mathiesen, "Smart energy and smart energy systems," Energy, vol. 137, no. May, pp. 556565, 2017.

[3] Raspberry Pi Foundation, "Raspberry Pi 3 Model B Technical Specifications," RaspberryPi 3 Model B, p. 8, 2016.

[4] R.S. Pressman, "Prototype", dalam Software Engineering A Practitioner's Aproach, Thomas Chasson, 2001, pp. 31-32.

[5] D. Hirawan and P. Sidik, "Prototype Emission Testing Tools for L3 Category Vehicle," IOP Conference Series: Materials Science and Engineering, vol. 407, p. 012099, 2018.
[6] G. Subagja, D. Hirawan, "Purwarupa Sistem Monitoring Keamanan Toko Emas Family S Berbasis Internet of Things".

[7] D.J. Sudrajat, "Tinjauan Standar Mutu Bibit Tanaman Hutan dan Penerapannya di Indonesia," Tekno Hutan Tanam., vol. 3, no. 3, pp. 85-97, 2010.

[8] T. Marrs. "JSON at Work: Practical Data Integration for the Web". O'Reilly. 2017.

[9] Munawar, "Analisis dan Peranccangan Sistem Berorientasi Objek dengan UML,". Informatika. Bandung. 2018.

[10] S. Desikan and G. Ramesh, "Software testing: Principles and practice". Bangalore, India: Dorling Kindersley (India), 2006. 